\title{
Global-local imbrications in education policy: Methodological reflections on researching the sociology of Teach for Bangladesh
}

\author{
Rino Wiseman Adhikary* - University of Queensland, Australia \\ Bob Lingard - Australian Catholic University, Australia
}

\begin{abstract}
This article documents the methodological thinking that underpined a sociological study of Teach for Bangladesh (TFB), a globally mobile yet locally embedded education policy situated in a developing world context. In order to reassess education policy vis-à-vis spatialities-power, relationships-resources, culturechange and imaginations-flows of globalization, this methodological thinking has to be both flexible and innovative. Analysis (topological) has demanded a combination of global ethnography and network ethnography, the former allowing global forces to be understood as spatially and culturally imbricated within intersecting policy worlds ([g]local cases), and the latter mapping and analysing spaces (networks and relations) and places (cultural negotiations) that characterize power within such imbrications. Data were collected both online and on site, resulting in both empirical advantages and practical challenges. As a sociological attempt to study policy mobilities in education in a Southeast Asian context, this study offers an innovative methodology and a befitting set of analytical vocabulary.
\end{abstract}

Keywords: globalization, topological analytics, policy sociology of education, network ethnography, global ethnography, methodological challenges, Teach for Bangladesh

\section{Introduction}

This article provides an account of the methodological thinking that underpinned our research on the localization of a global reform in teacher education in a developing world context, specifically in Bangladesh (see Adhikary, 2019; Adhikary and Lingard, 2018; Adhikary et al., 2018). The research examined in sociological terms how a global teacher education policy model, Teach for America/All (TFA/All), was locally institutionalized and embedded (see Ball et al., 2017; Ozga, 2005; Ozga and Jones, 2006) in Bangladesh as a non-governmental organization (NGO)-cum-social enterprise (SE), Teach for Bangladesh (TFB). Here, we reflect on how we addressed the methodological and analytical challenges that this sociological investigation gave rise to through the global and local enmeshing within the research topic of philanthropic influence (think of TFAll) in education policy (Tompkins-Stange, 2016) in Bangladesh (think of TFB). Such a novel sociological approach to studying education policy, particularly in the Southeastern context as it faces globalization, demanded a new methodological approach and a set of analytical vocabulary to make justifiable sense of TFB as a mobile policy. 
Broadly, the backdrop of this study was neoliberal economic globalization and the associated influence of philanthrocapitalism (Bishop, 2007) on educational policy and governance. Often referred to as 'creative capitalism' (Gates, 2008), this new philanthropic (Ball and Junemann, 2012) phase of global capitalism seeks to solve social problems by funding and localizing reforms through impact investment and associated programmes (Allman and Nogales, 2015). Such social investments are translated into social impact by motivated actors who manage philanthropic investments through local SEs (see Ball et al., 2017; Olmedo, 2017). These social entrepreneurial programmes are designed to steer policy by gradually becoming demonstrators of best service management practices to national governments. In such cases the goal is usually convincing the government in favour of upscaling the programme nationwide, a process that involves legislation and policies (see Ball and Junemann, 2012); the programmes are policy catalysts and their enactment requires relevant systemic policies and structural reforms.

Initially, TFB's social entrepreneurial identity signalled a project case (Peck and Theodore, 2015) that was capable of explaining relational quotidian efforts of relevant actors, their imaginations and the associated flows of resources that potentially operationalized a global philanthropic policy aspiration within the local education policy landscape in Bangladesh. We see policy as aspiring in most instances to create an imagined future that involves a networked community, its common aspiration/s and associated cultural formulations (Appadurai, 1996). Peck and Theodore, for example, regard imagining policy as the prefiguring of that future, and they also suggest that policy imagination today has been debordered (Peck and Theodore, 2015: xv), an idea they describe as a 'policy world' (also see Shore and Wright, 2011). Considering its networked link with the globalized prototype TFAll, the localized TFB (de Sousa Santos, 2002) hypothetically presented an organizational case that addressed the global-local imbrication in its programmatic enactment of the intended policy that both represented. Beginning with the aim of tracking global philanthrocapitalist codes through TFB's organizational DNA (Tompkins-Stange, 2016), our sociological approach to TFB therefore explored practical, transactional, circulatory and negotiatory processes of globalization and their impact on education policy and governance in Bangladesh. Furthermore, the relevance and applicability of such an onto-epistemological view of this developing world policy setting demanded examination, given the absence of such research to date.

However, a synthesis of theoretical and methodological reflections during and after the empirical fieldwork revealed that understanding TFB as an organization and in relation to its global network would be partial if we did not undertake a nuanced examination of TFB's link to the history of SEs in Bangladesh - the context of the context (see Peck and Theodore, 2015: 39; Brenner et al., 2010; Ball et al., 2017). Particularly important were the path dependent transformations in the primary education policy landscape and more recent developments in the NGO sector. Consequently, our attention shifted to a spatiocultural focus on SEs vis-à-vis policy and governance of education in Bangladesh. Onto-epistemologically, we now viewed TFB's social entrepreneurial policy influence in terms of 'policy worlds' (see Shore and Wright, 2011).

Like other imagined worlds, policy worlds are animated by networks, common aspirations, and discursive and ideational images, all of which are carried along by the disjunctive dimensions of global cultural flows (see Appadurai, 1996). Starting with TFB and guided by this spatiocultural perspective to policy, two interlinked policy worlds of larger systemic impact, and which formed the policy conditions necessary 
for the inception and functioning of TFB, were identified and studied in a triadic interrelation. Within these three policy worlds, TFB, the British Council Bangladesh and a donor consortium respectively influenced relevant government authorities that were the gatekeepers for social entrepreneurial involvement and accompanying global partnerships in the education and NGO sectors. Our flexible approach to these three policy worlds (or fields) was methodically different from one another, yet enabled comparison of overlapping policy regimes (see Peck and Theodore, 2015: xix) that functioned locally but were endowed globally. These were three overlapping cases (or worlds or fields) (Burawoy, 2009; Peck and Theodore, 2015) of social entrepreneurial policy within which we sought to decipher how global-local imbrications in policy manifested glocally (see Lingard, 2014; Robertson, 1994).

Thus, the methodological challenges were multifaceted: we identified and flexibly addressed three of them in our research. The first was the framing of research questions, and whether we should begin with a theory-driven approach to inquiry. If not, why not, and if so, then what theories would suffice, when, and how? Linked to this was the second difficulty: the conceptual framing of onto-epistemological reasoning capable of capturing the global-local imbrications so that theory and empirical knowledge informed and developed each other (Merriam and Tisdell, 2016; Suter, 2012). A 'topological analytics' was the outcome of such reasoning, which thus determined the scope and conceptual framing of data collection and analysis in terms of three 'policy worlds'. The third struggle involved strategic application of methods and techniques to capture the global-local imbrications within the three policy worlds that would enable answers to the research questions. Sociologically, we sought to examine the ways these three worlds of policy augmented, as well as differed from, each other, in the way policy influence was constructed through global-local overlaps.

\section{The framing of the research}

TFB was the pivot around which our research thinking initially revolved and then evolved. The corresponding author of this article had some knowledge about and working experience with this local NGO-cum-SE in Bangladesh. A series of supervised discussions created the impulse for researching TFB. Yet a few fundamental questions stood in the way of such a resource-demanding undertaking. For example, insomuch as education policy and governance were concerned, did TFB have a worthwhile story to tell? After all, at face value it appeared simply to be a local NGO. If it did have a story, why was it important, particularly for a developing country such as Bangladesh? Could such a story contribute substantial knowledge to policy sociology? What would that knowledge add up to in terms of methodology, theory and practice in relation to Bangladesh, but also to globalization? These questions gained traction particularly because similar studies with a specific focus on philanthrocapitalism and education policy have been conducted mostly in the developed world contexts (see Au and Ferrare, 2015; Elliott, 2018; Friedrich, 2014; Friedrich et al., 2015; Labaree, 2010; Lefebvre and Thomas, 2017; Smart et al., 2009; Straubhaar and Friedrich, 2015; Yin et al., 2019; Thomas, 2018b, 2018a). This body of literature, however, provided practical insights into how TFAll has materialized, particularly in its host countries, with prototypical idiosyncrasies.

Seeking insights, we performed an internet-based fact-finding search for TFB. A few points caught our immediate interest. First, TFB publicly declared its mission of changing the whole primary education subsector/system in Bangladesh (hereafter PESoB). This provoked reflections on power, authority and resources in relation to the 
possible transformations in policy and governance of PESoB. Related to this was a second observation: TFB actors were found to be interacting with a few high-level government officials in order to work within select government primary schools in less affluent areas. This was a partnership-based and radically different approach that it was hard to imagine taking place even a few years back. Third, TFB was an active node within a global policy network (TFAIl) that proselytized a social entrepreneurial model of alternative teacher education in more than 40 countries. Despite its base in Dhaka, TFB was proactively participating in this policy network. Furthermore, TFB appeared to be significantly globally endowed. Its funding relation with global philanthropies (see Adhikary and Lingard, 2017) indicated that it was rooted in a philanthrocapitalist policy culture. Fourth, the TFB founder was an American citizen, although of Bangladeshi origin, and was highly globally mobile. She was part of a Bangladeshi diaspora. And lastly, the organization preferred to identify itself as an SE, although it was listed at the NGO Affairs Bureau of Bangladesh (NGOAB) as a local NGO. What was so important about being an SE or an NGO-cum-SE, rather than a traditional NGO?

These intriguing observations presented a few important themes in consideration of the extent, intensity and scale of our research thinking. First, as an organization TFB declared itself as intending to influence the policy and governance of PESoB, or at least a substantial part of it. In this sense, when studied sociologically, TFB demonstrated the potential to facilitate understanding of the actors, discourses, mechanisms and conditions that enabled such philanthropically endowed global reform policies in Bangladesh. Second, TFB's link to the TFAll global network implied that the 'change discourse' potentially linked to something global and intuitively larger: hypothetically, global philanthrocapitalism and its local manifestation of policy influence. Third, TFB's connection with government authorities and work within government classrooms signalled that the sought-after change had to deal with an intended reform in teaching/learning policies and practices in public elementary schools. Fourth, the social entrepreneurial galvanization around TFB's NGO identity signalled a transitory phase in the long history of mainstream NGO work within Bangladesh's education landscape. Fifth, the organization appeared to be nested within networks and flows of various resources. Such flows of actors, money, knowledge, images and technology underpinned the relevance of globalization in understanding TFB. Finally, and this became the overarching theme of the study, TFB presented itself as a container of global-local imbrications in every aspect of these initial observations.

Such internet-based findings presented TFB as a local/izing carrier of a global reform policy in teacher education, highlighting the relationships, actors and organizations central to TFB's enactment. These observations also signalled transformations in social entrepreneurial policy and governance within PESoB and NGO sectors in Bangladesh. While the local policy efforts were gradually moving towards more partnership-based forms of teacher preparation, TFB presented itself as an exemplar of such a partnership model. Here, TFB appeared as an opportunity to observe the practical manifestations of performative processes and enabling flows of globalization in relation to policy mobilities and mutations within a local policy landscape. Thus, in relation to the empirical, a sociological appreciation of TFB meant studying policy mobility and enactment together in relation not only to globalization and associated transnational influences but also to two local landscapes of policy and governance (i.e. PESoB and NGOAB). Although field observations provoked theoretical reflections at this point, the immediate use of theory seemed inhibitive to the 'natural' flow of observational common-sense, risking theoretical overdetermination. 
Aligned to Peck and Theodore's (2015: 30) 'pursuing projects' (i.e. TFB) approach to 'following [global] policies' (Ball et al., 2017: 15), we decided to allow TFB to tell the story and guide our intrigues, intuitions, questions and, therefore, our theory thinking. At this stage, the research questions were not directly supported by specific theory. Rather, quite advantageously, the fact-finding observations on TFB offered a few reflective themes that would enable us to frame a tentative set of research questions before getting into the field for data collection. Keeping such broad themes still in the background, we decided to stay close to what TFB had to offer at first glance and then take it from there. We asked simple questions: what is TFB? Was there a policy at all? If so, how was it constituted globally and locally? And under what policy conditions? However, particularly during our fieldwork, we discovered that TFB was more than a local organizational career of globalized reform. It was locally nested in histories of cultural and structural transformations within the PESoB and NGO sectors, which continue to create the supportive policy conditions that are necessary for social entrepreneurial policy, leadership and management of education. PESOB had transformed itself through the utilization of various forms and levels of network governance, while the NGO sector had also been embracing that modality. As a consequence, we opted for studying TFB as a gateway to such system level transformations.

In the course of the fieldwork, theory filtered into interesting empirical discoveries about the various ways in which TFB demonstrated its global-local imbrications as both a mobile and an embedded policy. The fieldwork also revealed that TFB needed to be understood in terms of the structural and cultural transformations within the PESoB and NGO sectors with regard to social entrepreneurship. Cross-checking our initial observations about TFB with the ongoing empirical reflections we were making during and after fieldwork, we identified the relevance of theories of globalization, of governance and of policy in relation to education. Analytically combining these three theoretical lenses, we reappraised and adapted what has been referred to as a 'topological analytics' of spatialities, culture and power in globalization, and therefore in global policy influence (Amin, 2002), something that we consider in the next section. The fundamental goal of this conceptual work was to develop an onto-epistemological heuristic for understanding how power is constituted within the global-local imbrication of influence (i.e. globalization) in contemporary mobilities of global policies and their local reformulation (mutation/enactment).

\section{Globalization and power: A topological appreciation of education policy and governance}

For the purposes of this research, we argued that globalization is primarily a respatialization of governance and an associated reconfiguration of culture and power. Characterizing such new modes of governance, aspirational networks of culture and imagination, relationships of resourcefulness and technology-aided mobilities, flows and (topological) connectivities are increasingly mattering more as emerging forms of power and carriers of influence than territorial and temporal situatedness and associated structural expressions of formal (topographical) authority. Thus, the localization of a globalized policy (de Sousa Santos, 2002) involves global-local imbrications of power through spatialities of cultural influence (forms of places and spaces). Such spatialities contain inherent tensions between topological and topographical subjectivities (see Appadurai, 1996; Lingard, 2014). It is within and through such spatialities that cultural formulations enabled by globalization are initiated, worked out, negotiated, politically processed and normalized. This is how the global transnational aspirations, power and 
influence acquire reach (Allen, 2009) and then get 'moored, bounded and stabilized' (see Fenwick et al., 2011: 12, 143-7; Takayama et al., 2017) locally, but in mutating ways (Peck and Theodore, 2015), often involving assemblages of the older and newer forms of intuitional power, formal authorities and cultural formulations (Savage, 2018).

\section{Globalization: Power, spatialities and culture}

If globalization is viewed this way, an understanding of today's education policy invites consideration of the influential and altering roles that aspiring global actors, the power resources that they mobilize and the technology-aided networks and cultural flows that carry them play in reaching, interacting with, influencing and clearly transforming territorial structures and authorities. This is to say that today's education policy and governance need to be appraised topologically in the context of globalization, and inter alia along three axes - spatialities, culture and power - through which, perhaps, any form of global influence is rationalized and imbricated with/in local landscapes of policy and governance, and in some cases vice versa (see Figure 1).

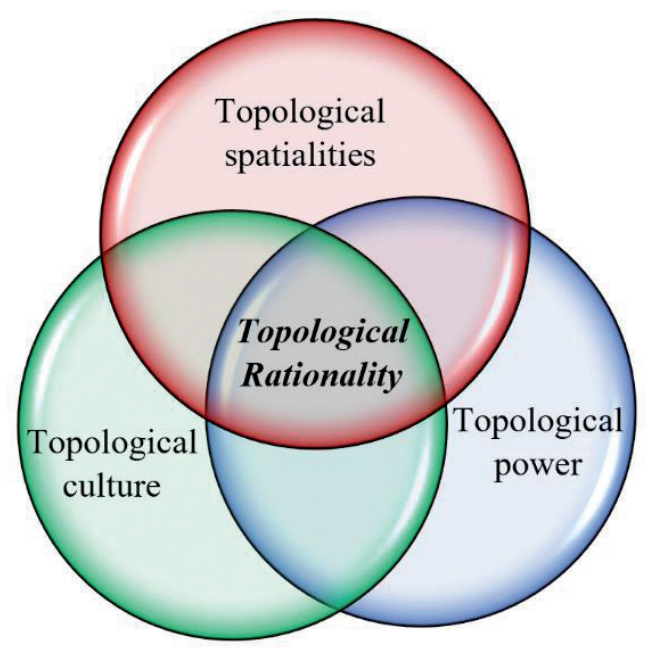

Figure 1: Three axes of topological rationality

Significant theories of globalization talk about the cultural dimensions of disjunctive global flows (of people, money, media, technology and ideas/ideologies) (Appadurai, 1996), and the globalization and localization that such flows manifest (de Sousa Santos, 2002) within various global fields (Bourdieu, 1993; Lingard and Rawolle, 2011). This dynamic is also explained in terms of the politics of scale and associated power shifts within states (Brenner, 2004; Jessop, 1998, 2000; Robertson and Dale, 2008). Such politics is geopolitically explained as time, space and distance compression (for example, Amin, 2002; Thrift, 1999) resulting inter alia in the rise of powerful global cities (Sassen, 2007, 2013). In this global context, sociopolitical action is increasingly being reorganized spatially and culturally as and through networks (Amin, 2002; Castells, 2000; Massey, 1994; Thrift, 1999), which have substantially changed the way in which states now function in terms of governance (Rhodes, 1997; Rosenau, 1997; Ball, 2013, 2012). Yet the older territorial and scalar understanding of the state represents one ongoing aspect of power (Allen, 2009, 2011).

These theories basically relate to power in and of governance, marking the deeper and wider sociopolitical and cultural respatializations (geospatial politics) that have been 'admixed' (Williams, 2005), creating new modes of emergent power in the 
arena of governance. Such nascent spatial and cultural forms of power supplement and compete with older residual ones, all affected by the dominant forces of neoliberal globalization (Williams, 2005). Our spatialities approach to policy influence embraces the residual as well as the powerfully nascent roles of agency (Appadurai, 1996), structure (Peck and Theodore, 2015) and scale (Papanastasiou, 2017). For one thing, the context of these transformations is characterized by complex dynamics of flows, fields, scales, spaces and relationships, which can be understood as spatialities or spatializations. For another, these spatialities and relationships are results of powerful agentic imaginations and mobilizations that impact the topographical nature and functioning of power in and through culture, politics, policy and governance.

In this sense globalization changes the geometry of power through the spatial reorganization of the governance of society (see Castells, 2016: 2; Held et al., 1999: 16). If spatial organization is the 'outcome' of 'attempts to use space efficiently' (Adams, 1971: 54; Morrill, 1974), an attempt to efficiently organize sociospatial action is practically an act of governing social life by setting new scales, relations, fields and rules of the game. Such spatial deformations and reformations are the results of powerful global imaginations that manifest into 'imaginary worlds' (Appadurai, 1996), in our case, of education policy (Peck and Theodore, 2015; Wright, 2011; Shore and Wright, 2011). Such transformations associated with globalization (see Held et al., 1999: 16) conjure a global field of governance (see Rizvi and Lingard, 2010; Parreira do Amaral et al., 2019; Ball, 2012; Ball et al., 2017; Lingard and Rawolle, 2011), wherein agency, influence and culture impact through spatial reorganization of movements, spaces, distances and demarcations that hitherto defined the sociality and culture of economy and politics. As such, capabilities associated with networks, flows and connectivities translate into an ability to mobilize competitive resources - the emerging form of power (see Castells, 2016; Held et al., 1999).

However, the cultural content of this newly emerging form of power is change as a normalized continuum (Lury et al., 2012: 5). As a transformative process of respatialization, globalization opens up new horizons of possibilities and continuities of cultural formulations - think of education policy here - particularly for those (state actors included) who can flow, travel and network, and thereby connect, facilitate and exercise power in differing degrees to imagine and materialize change. Indeed, under globalization, imagination has become a social form of work (Appadurai, 1996), while culture is no longer territorially defined as a historical constant. While culture has evolved from being changeable to change itself (Lury et al., 2012), change as the perpetual goal is measured by spread, depth, speed and acceleration of the formulative processes of culture (see Held et al., 1999: 16) - global-local impact.

The emphasis on flows, relationships and connectivities, both in practice and in theory, constitutes the topological or relational 'logic' that, according to Amin (2002: 386), offers a 'heterotopic' (Foucault, 1986: 24-6) understanding of spatialities, in this case of policy influence. In this heterotopic sense, places need to be conceptualized as sites in networked or virtual spaces of organization' (Amin, 2002: 386). While place is viewed as a site of/for 'placements of practices of varied geographical stretch' (i.e. policy/reforms), space is understood as 'immanent forces' of various kinds: discursive, emotional, affiliational, physical, organizational, virtual, technological and institutional (Amin, 2002: 386). Spaces are also carriers of 'organization, stability, continuity, and change' (ibid.), again of and through policy. With the topological, relations are more important than locations.

Therefore, network as a form of cultural spatiality has a net dimension, which is the immanent space of agentic force that seeks to organize and govern. It also has a 
work element that represents the placement and anchoring of practice (i.e. place of cultural negotiation and formulation). Allen $(2009,2011)$ rightly sets out the equation 'network = net + work', highlighting that both space and place (spatialities) are at work: net in the sense of webbed space/s of relations and connections with collective aspirations and cultural imaginations (Appadurai, 1996) and work as the negotiated placement of practice (culture of policy) in the form of place. In this sense, a global policy underpinning local change is a process of construction and negotiation of culture through different spatialities. This culture is imagined and represented by spaces (networked actors and organizations) and is negotiated in/as places through hands-on quotidian labour/work (Ball et al., 2017). However, although the topological nature of 'netting' (making and casting of a net) is quite obvious, such topological manifestations also characterize the local work side of the net. This is because even a locally grounded 'policy labour' (Avelar, 2018; Ball et al., 2017) may involve practical onsite work with an underlying primacy of relationalities and connectivities (Allen, 2009, 2011) of local power.

\section{Education policy and governance: Philanthrocapitalism, networks and heterarchies}

Three interrelated terms/concepts adequately consolidate current scholarship on policy and government vis-à-vis globalization: governance, networks and heterarchies (Ball and Junemann, 2012; Rhodes, 1997, 2012). Governance basically denotes the many different ways in which national governments now act by accepting, enabling, allowing and partnering with numerous non-and-beyond-state actors that seek to acquire and exercise shared authority in order to identify and solve intractable social problems. While the global rise of governance is linked to neoliberal ideology and New Public Management (Wennström, 2016; Clarke, 2004), governments now partner with actors as varied as NGOs, international NGOs, quangos, corporations and private organizations, global funds and investment funds, local representations of global civil society, multi/bilateral donor agencies, and philanthropic individuals and foundations. Evidently, these transnational forces, institutional authorities and sociomoral agencies of culture combine and cut across all the imaginable sites, scales and sources of power to govern.

Of these actors, global philanthropic foundations, their patrons and programmes are becoming increasingly visible through their efforts to partner with and influence governments in myriad ways and now on a global scale (Bigham et al., 2016; Bishop, 2007; Hess and Henig, 2015). Underlying this new philanthropic governance are the market aspirations (systemic imaginations) and social innovations (culture) of global philanthrocapitalists. Often referred to as policy patrons (Tompkins-Stange, 2016), these philanthropists fund programmes that topologically fold globally intended reforms within programmes (Allen, 2011; Amin, 2002; Lewis, 2016), only for them to be unfolded and embedded within distant jurisdictions. As such, global philanthrocapitalism combines a nascent philanthropic governmentality (imagination) with mercantile rationalities and programmatic modes of managerialized charity (change). With the goal of steering policy towards nationwide upscaling of funded and demonstrated models, such programmatic policy undertakings are managed and embedded locally by social entrepreneurs (Adhikary and Lingard, 2017).

The vessels that carry and transmit such programmes and enabling resources are various forms of networked spatialities. Led by individuals or groups, such networks connect and mobilize actors, of whom a few function as sources of resources and a few others as localizing policy labourers (Ball et al., 2017). These actors and organizations 
demonstrate globally endowed resourcefulness alongside their ability to compress territorial distance and temporal difference in the ways they interact, influence and partner with national governments. As was found in our research, the national government often also reaches out to such actors (Adhikary, 2019), as actors become increasingly more economically capable and assume influence within or derive it from various national conduits of authority and international circuits of institutional and financial power (Tompkins-Stange, 2016: 90).

Recent scholarship on educational governance identifies such developments as explaining a globalized move from government to what has been described as network governance (Ball and Junemann, 2012; Ball, 2012). This is governance by and through policy networks. Ball and Junemann (2012: 9) identify two major trends in conceptualizations of policy networks - one speaking of the general changes in the form and functioning of government-facing waves of neoliberal restructurings (Rhodes, 1996, 1997, 2009, 2012); and the other denoting an array of social relationships influencing and shaping education policy (Ball, 2012, 2013; Ball and Junemann, 2012). The latter trend particularly highlights the emergence and steering role of new philanthropy and associated social entrepreneurial forms of localized programming. Yet both trends in some way complement each other and mark the changing role of governments in mediating policy influences, which heterogeneous and networked relationships bring into the equation of governance and power.

Thus, policy networks are a form of governance that entwine market and state, aiming to create regime(d) spaces of governance. In the context of philanthrocapitalism, network governance demonstrates a set of social relations - a constructed policy community or community of practice - that draws initial deliberative force, funded agency and leading discourses (for example, disadvantage, meritocracy, enterprise, investment and impact) from philanthropy and business (Ball and Junemann, 2012: 58). It is a mode of governance in as much as it is capable of playing a steering role, of setting directions and of influencing behaviours underpinning policy and governance (ibid.: 138; Parker, 2007: 114). Policy networks themselves have become interested global carriers of policy, although not in the linear one-way sense of policy 'trafficking' (Peck and Theodore, 2015: xv). Policies are uploaded into constructed global/ transnational spaces by and as networks. They are then downloaded in various settings and embedded/anchored institutionally through practical hands-on and on-site policy labour of aspiring glocal actors (a combination of global, local and hybrid actors) (Ball et al., 2017: 9). This explains the explanatory fit of the 'net + work = network' thesis visà-vis education policy and governance today.

In the process of net + working, the power to govern lies in the ability to involve connections, communications, relations, and resource exchanges (Ball et al., 2017). It is through this relational and connective power (not yet authority) - 'connective tissue' (Ball, 2012: 5) and the muscular power of it (Hess and Henig, 2015: 2) - that policies are moved and then embedded through policy labour that interacts with the traditional structures of authority, delivery systems and frames of meanings of education. Policy networks in education now perform both globalizing and localizing work, changing education policy and governance both structurally and culturally. These networks have their local, global and transnational dimensions of structure, rootedness and flows; yet they also become functionally effective through glocal hands at work and glocally created local spaces of policy - 'globalising microspaces' (Ball et al., 2017: 12, 59; Cook and Ward, 2012: 142), such as TFB. These globalizing microspaces seek to create and leverage 'regimes of trust' (Larner and Le Heron, 2002: 418) or 'policy regimes' (Peck and Theodore, 2015: 29), which are also 'regimes of knowledge' (Parreira do Amaral, 
2019: 116) and of 'power' (Shore and Wright, 2011: 19). We understand them as regimes of policy culture - heterarchies (Ball and Junemann, 2012) that seek to govern through policy networking as a shared form of authority (Rosenau, 1997: 145). That is, a few key actors within such policy networks eventually succeed in acquiring some degree of authority in the form of negotiated and agreed partnerships, and thereby become locally embedded heterarchies. Indeed, the global and the local are thus imbricated through the work of networks.

\section{Discussion and conclusion}

The topological view of globalization, education policy and governance resulting from on- and post-field empirical reflections necessitated methodological rethinking as we approached TFB both spatially and culturally. That is, alongside its spatial nature as a locally embedded organizational carrier of globally networked policy influence, TFB also highlighted a significantly impactful cultural content of policy - change (systemic reform) in social entrepreneurship terms. This focus on TFB as a social entrepreneurial policy culture also resulted in the identification of its links and situatedness within the two larger national sectors, namely the PESoB and the NGO sectors, which were historically and concurrently mediating different spatiocultural forms of policy influence, indicative of a rising policy environment of social entrepreneurial reorganizations in systemic and service governance. The latter two created the broader policy environment/conditions necessary for TFB's inception and functioning - the context of the context (Peck and Theodore, 2015: 39).

To be specific, the British Council Bangladesh (BCB) led a networked policy advocacy movement to influence the NGOAB's nationwide social entrepreneurial sector policy, while a networked donor consortium (DC) under the World Bank's lead influenced the Ministry of Primary and Mass Education through the Primary Education Development Programme. The BCB's influence was more contemporary and movement-like, while the DC demonstrated structural adjustments that moved path-dependently towards the social entrepreneurialization of educational policy and governance. Consequently, we identified three overlapping cases of policy influence that we decided to study sociologically as constitutive of three imagined and enacted worlds of policy (Appadurai, 1996; Burawoy, 2009; Ozga, 1987; Wright, 2011) and of the associated cross-field effects (Lingard and Rawolle, 2004).

In this regard, and viewing globalization primarily as cultural processes, Appadurai (1996: 33) conceptualizes global agency (individuals, organizations and movements, etc.) as the creators of 'multiple' 'imagined worlds' that are first aspiringly imagined and then culturally created and lived by these agents, involving mediating locals. Indeed, global imagination has become a social act/work and meaningful social life (Appadurai, 1996) to those who are capable of such developments (for example, global philanthropists) (see also Tompkins-Stange, 2016). The resulting imagined worlds are composed of imagined community (network), imaginaire (collective aspirations) and images (cultural formulations) (Appadurai, 1996: 31). Presenting a similar 'world' view of global agency, Burawoy (2000: 27-31) talks of mediators (particular actors' interests, beliefs and values), their global connections (chains, flows and networks) and associated ideological and power images that are produced and disseminated.

Consequently, policy worlds are first imagined and then animated by networks of actors, collective aspirations and purposive cultural formulations. In this sense, imagined and manifested policy worlds are composed of networked spaces of influence, common aspirations of a community of actors/practice, and places/platforms/surfaces 
of cultural negotiation and formulations. The key to sociological investigation, in our case, was the identification of core policy culture and then the prying open of windows (Tompkins-Stange, 2016) to policy worlds that contained different variants of such a policy culture: we found three in this case. Shore and Wright's (2011) conceptualization of 'policy world', to which Peck and Theodore (2015) subscribe, provided a beneficial ontology for our policy sociology:

'policy worlds' does not imply essentialised or bounded entities; rather, we see policies as windows onto political processes in which actors, agents, concepts and technologies interact in different sites, creating or consolidating new rationalities of governance and regimes of knowledge and power. (Shore and Wright, 2011: 2)

However, given the processes of globalization in the face of globalization, the material realization of these imagined policy worlds is contingent upon the disjunctive flows of people, money, media, technology and ideas/ideologies that give rise to various scapes, such as ethnoscapes, financescapes, mediascapes, technoscapes and ideoscapes (Appadurai, 1990: 296), even policyscapes (Ball, 2013; Carney, 2009). Appadurai (1996: 31-3) argues further that disjunctures between such flows within 'multiple imagined worlds' constitute the politics of global cultural formulations. Although often disjunctive, these cultural flows are power resources that constitute and sustain the worlds of policy. Identifying such disjunctures and how they were resolved through policy socialities within the identified three worlds of policy became our core task. It is in such disjunctures that negotiation and persuasion revealed their functional and relational details underpinning power.

In undertaking this sociological work of following policy, we combined empiricalanalytical methods of network ethnography and global ethnography. While global ethnography advantageously presents the local as the empirical container (worlds) of the global (Burawoy, 2009; Peck and Theodore, 2015), network ethnography offers practical and innovative ways of capturing the relations, resources, spatialities and culture that materialize such containing (Ball and Junemann, 2012; Hogan, 2016; Howard, 2002). The application of this dual-method strategy meant that our researching data re/sources were as varied as official websites, social media pages, posted videos and photos, online news articles, TV talk-shows and interviews, inaugural speeches, panel discussions, government documents, programme proposals and policy dialogue events; all eventually informed and orientated the ethnographic semi-structured interviews central to the on-the-ground data collection of the study.

Owing to the adoption of a policy world ontology and the associated dualmethod epistemology, data collection was necessarily a flexible process. We started with a network ethnographic approach to TFB and generated network maps of actors and flows of resources through which the global-local imbrications occurred. We then followed the identified network in the field, not only to collect their interviewed opinions and perceptions, but also to tap into what they were doing practically on the ground. It is through such sociological prying that the policy worlds emerged, and they were then investigated by focusing on social entrepreneurship as the overarching policy culture. Following policy networks and then following policy worlds vis-à-vis the dominant cultural formulations entailed practical challenges. For example, we needed to seek gatekeepers' permission from government bodies that represented authority within the identified policy worlds, as the study involved specific national fields and sectors. If we had simply followed the network, these gatekeepers' permissions would not have been necessary. 
Following the social worlds and the quotidian engagements through which placement of practice (social entrepreneurial reforms as culture) were negotiated and enacted was difficult. Such heterotopic sites were usually constructed internally and were intended for networked actors and invitees. Gathering accurate news of such events (meetings, panel discussions, policy dialogue, seminars, etc.) and accessing them with authorization (often mediated and brokered in cases of absence of standard protocols) or invitation was indeed painstakingly challenging as a mode of data collection. The spatiocultural perspective on policy as constructed worlds by default meant that the embedded disjunctures of various flows therein were to be dismantled and examined. That is, we endeavoured to tap into the often conflicting yet mobilized flows of various resources to understand what resolved inherent disjunctures; and indeed in all identified cases it was topological relationships that solved such conflicts. Such data (financial, transactional, programme documents, legislations, contracts) often had to be collected not from the actor under investigation, but from government sources, following roundabout routes.

Deciphering disjunctures in relation to respective policy worlds through interviews and attended events was often risky in relation to the respondents' political, ideological, administrative and cultural orientations. This was particularly the case because the competing interests and values from various fronts were clearly identifiable, and we had to be careful in navigating such competitive places. In this regard, the curiosity of research participants about the identities and views of other participants was noted. However, apart from interviews, we also looked into various topological surfaces and places (Lury et al., 2012; Manning, 2009; Parisi, 2012), both online (for example, Facebook pages) and on site (for example, policy dialogue events), where social entrepreneurial policy was culturally constructed, contested and negotiated. These topological surfaces empirically evidenced not only the cultural (re) formulation of the policy through discursive technologies and ideational images, but also the dominant actors who imagined such culture globally and locally.

Although the locally grounded net and its policy work within each policy world were identified and investigated within a given amount of time and limited resources, we felt it important to connect with some of the distant philanthrocapitalist actors (TFAll, Porticus, etc.) whose aspirations, policy imaginations and mobilized resources were being processed locally by glocal hands. Owing to a lack of resources and time, and considering our focus to be more on the sociality of the localization process, we were not able to do this. That is, we were not able to interview some of the nodal philanthrocapitalist actors, although that would have been illuminating. To conclude with an observation on the researcher's subjectivity, we - one of us from the Developing East and the other from the Developed West - continually negotiated and informed each other's worldviews in the processes of data collection, resulting in reflexive transformations of our researcher positionality (Bourdieu, 1990).

\section{Acknowledgements}

This research received support from an Australian Government Research Training Program Scholarship, provided by the University of Queensland, Brisbane, Australia.

\section{Notes on the contributors}

Rino Wiseman Adhikary recently completed his doctoral degree in education from the University of Queensland, Brisbane, Australia. His area of research is global policy 
governance in education. His articles have appeared in the Journal of Education Policy, Discourse: Studies in the Cultural Politics of Education, Comparative Education, Policy Futures in Education and KEDI Journal of Education Policy.

Bob Lingard is Professorial Fellow at the Institute for Learning Sciences and Teacher Education in the Australian Catholic University, Australia. His most recent books include Globalizing Educational Accountability (Routledge, 2016) and Politics, Policies and Pedagogies in Education (Routledge, 2014). He is editor of the book series Key Ideas and Education (Routledge) and of the journal Discourse: Studies in the Cultural Politics of Education.

\section{References}

Adams, J.S. (1971) 'Review - The Spatial Organization of Society, by Richard L. Morrill'. Economic Geography, 47 (4), 555-6.

Adhikary, R.W. (2019) 'Globalization, Governance and Teach for Bangladesh: Understanding social enterprises in education policy'. Unpublished PhD thesis, University of Queensland.

Adhikary, R.W. and Lingard, B. (2018) 'A critical policy analysis of "Teach for Bangladesh": A travelling policy touches down'. Comparative Education, 54 (2), 181-202.

Adhikary, R.W., Lingard, B. and Hardy, I. (2018) 'A critical examination of Teach for Bangladesh's Facebook page: "Social-mediatisation" of global education reforms in the "post-truth" era'. Journal of Education Policy, 33 (5), 632-61.

Allen, J. (2009) 'Three spaces of power: Territory, networks, plus a topological twist in the tale of domination and authority'. Journal of Power, 2 (2), 197-212.

Allen, J. (2011) 'Topological twists: Power's shifting geographies'. Dialogues in Human Geography, 1 (3), 283-98.

Allman, K.A. and Escobar de Nogales, X. (2015) Impact Investment: A practical guide to investment process and social impact analysis + website. Hoboken, NJ: Wiley.

Amin, A. (2002) 'Spatialities of globalisation'. Environment and Planning A: Economy and Space, 34 (3), 385-99.

Appadurai, A. (1990) 'Disjuncture and difference in the global cultural economy'. In Featherstone, M. (ed.) Global Culture: Nationalism, globalization and modernity. London: SAGE Publications, 295-310.

Appadurai, A. (1996) Modernity at Large: Cultural dimensions of globalization. Minneapolis: University of Minnesota Press.

Au, W. and Ferrare, J.J. (2015) 'Introduction: Neoliberalism, social networks, and the new governance of education'. In Au, W. and Ferrare, J.J. (eds) Mapping Corporate Education Reform: Power and policy networks in the neoliberal state. New York: Routledge, 1-22.

Ball, S.J. (2012) Global Education Inc.: New policy networks and the neo-liberal imaginary. London: Routledge.

Ball, S.J. (2013) The Education Debate. 2nd ed. Bristol: Policy Press.

Ball, S.J. and Junemann, C. (2012) Networks, New Governance and Education. Bristol: Policy Press.

Ball, S.J., Junemann, C. and Santori, D. (2017) Edu.net: Globalisation and education policy mobility. London: Routledge.

Bigham, J., Karmali, F. and Rundle, J. (2016) The Evolving Role of Philanthropy in Global Problem Solving. Global Solution Networks. Online. https://tinyurl.com/y3mp63m8 (accessed 11 August 2019).

Bishop, M. (2007) 'What is philanthrocapitalism?'. Alliance, 1 March. Online. https://tinyurl.com/y3otxo45 (accessed 11 August 2019).

Bourdieu, P. (1990) In Other Words: Essays towards a reflexive sociology. Trans. Adamson, M. Stanford: Stanford University Press.

Bourdieu, P. (1993) The Field of Cultural Production: Essays on art and literature. Ed. Johnson, R. Cambridge: Polity Press.

Brenner, N. (2004) New State Spaces: Urban governance and the rescaling of statehood. Oxford: Oxford University Press.

Brenner, N., Peck, J. and Theodore, N. (2010) 'Variegated neoliberalization: Geographies, modalities, pathways'. Global Networks, 10 (2), 182-222. 
Burawoy, M. (2000) 'Introduction: Reaching for the global'. In Burawoy, M. (ed.) Global Ethnography: Forces, connections, and imaginations in a postmodern world. Berkeley: University of California Press, 1-40.

Burawoy, M. (2009) The Extended Case Method: Four countries, four decades, four great transformations, and one theoretical tradition. Berkeley: University of California Press.

Campos de Avelar Maia, M. (2018) 'Giving with an Agenda: New philanthropy's labour in "glocal" education networks of governance'. Unpublished PhD thesis, University College London.

Carney, S. (2009) 'Negotiating policy in an age of globalization: Exploring educational "policyscapes" in Denmark, Nepal, and China'. Comparative Education Review, 53 (1), 63-88.

Castells, M. (2000) The Rise of the Network Society. 2nd ed. Oxford: Blackwell.

Castells, M. (2016) 'A sociology of power: My intellectual journey'. Annual Review of Sociology, $42,1-19$.

Clarke, J. (2004) 'Dissolving the public realm? The logics and limits of neo-liberalism'. Journal of Social Policy, 33 (1), 27-48.

Cook, I.R. and Ward, K. (2012) 'Conferences, informational infrastructures and mobile policies: The process of getting Sweden "BID ready". European Urban and Regional Studies, 19 (2), 137-52.

De Sousa Santos, B. (2002) 'The processes of globalisation'. Trans. Caldwell, S. Eurozine, 22 August. Online. www.eurozine.com/the-processes-of-globalisation/ (accessed 11 August 2019).

Elliott, J. (2018) 'Teach First organisational discourse: What are Teach First teachers really being trained for?'. Power and Education, 10 (3), 264-74.

Fenwick, T., Edwards, R. and Sawchuk, P. (2011) Emerging Approaches to Educational Research: Tracing the sociomaterial. London: Routledge.

Foucault, M. (1986) 'Of other spaces'. Diacritics, 16 (1), 22-7.

Friedrich, D. (2014) 'Global microlending in education reform: Enseñá por Argentina and the neoliberalization of the grassroots'. Comparative Education Review, 58 (2), 296-321.

Friedrich, D., Walter, M. and Colmenares, E. (2015) 'Making all children count: Teach for All and the universalizing appeal of data'. Education Policy Analysis Archives, 23 (48), 1-18.

Gates, B. (2008) 'A new approach to capitalism: Remarks delivered at the World Economic Forum, January 24, 2008, in Davos, Switzerland'. In Kinsley, M. and Clarke, C. (eds) Creative Capitalism: A conversation with Bill Gates, Warren Buffett, and other economic leaders. New York: Simon and Schuster, 7-16.

Held, D., McGrew, A., Goldblatt, D. and Perraton, J. (1999) 'Introduction'. In Held, D., McGrew, A., Goldblatt, D. and Perraton, J. Global Transformations: Politics, economics and culture. Stanford: Stanford University Press, 1-31.

Hess, F.M. and Henig, J.R. (2015) 'Introduction'. In Hess, F.M. and Henig, J.R. (eds) The New Education Philanthropy: Politics, policy, and reform. Cambridge, MA: Harvard Education Press, 1-10.

Hogan, A. (2016) 'Network ethnography and the cyberflâneur: Evolving policy sociology in education'. International Journal of Qualitative Studies in Education, 29 (3), 381-98.

Howard, P.N. (2002) 'Network ethnography and the hypermedia organization: New media, new organizations, new methods'. New Media and Society, 4 (4), 550-74.

Jessop, B. (1998) 'The rise of governance and the risks of failure: The case of economic development'. International Social Science Journal, 50 (155), 29-45.

Jessop, B. (2000) 'The crisis of the national spatio-temporal fix and the tendential ecological dominance of globalizing capitalism'. International Journal of Urban and Regional Research, 24 (2), 323-60.

Labaree, D. (2010) 'Teach for America and teacher ed: Heads they win, tails we lose'. Journal of Teacher Education, 61 (1-2), 48-55.

Larner, W. and Le Heron, R. (2002) 'From economic globalisation to globalising economic processes: Towards post-structural political economies'. Geoforum, 33 (4), 415-19.

Lefebvre, E.E. and Thomas, M.A.M. (2017) "Shit shows" or "like-minded schools": Charter schools and the neoliberal logic of Teach for America'. Journal of Education Policy, 32 (3), 357-71.

Lewis, S. (2016) 'Understanding New Spaces and Relations of Global Governance in Education: The OECD's PISA for Schools'. Unpublished PhD thesis, University of Queensland.

Lingard, B. (2014) 'It is and it isn't: Vernacular globalization, educational policy, and restructuring'. In Lingard, B. Politics, Policies and Pedagogies in Education: The selected works of Bob Lingard. London: Routledge, 86-104.

Lingard, B. and Rawolle, S. (2004) 'Mediatizing educational policy: The journalistic field, science policy, and cross-field effects'. Journal of Education Policy, 19 (3), 361-80. 
Lingard, B. and Rawolle, S. (2011) 'New scalar politics: Implications for education policy'. Comparative Education, 47 (4), 489-502.

Lury, C., Parisi, L. and Terranova, T. (2012) 'Introduction: The becoming topological of culture'. Theory, Culture and Society, 29 (4-5), 3-35.

Manning, E. (2009) Relationscapes: Movement, art, philosophy. Cambridge, MA: MIT Press.

Massey, D.B. (1994) 'A global sense of place'. In Massey, D.B. Space, Place, and Gender. Minneapolis: University of Minnesota Press, 147-55.

Merriam, S.B. and Tisdell, E.J. (2016) Qualitative Research: A guide to design and implementation. 4th ed. San Francisco: Jossey-Bass.

Morrill, R.L. (1974) The Spatial Organization of Society. 2nd ed. North Scituate, MA: Duxbury Press.

Olmedo, A. (2017) 'Something old, not much new, and a lot borrowed: Philanthropy, business, and the changing roles of government in global education policy networks'. Oxford Review of Education, 43 (1), 69-87.

Ozga, J. (1987) 'Studying education policy through the lives of policy makers'. In Walker, S. and Barton, L. (eds) Changing Policies, Changing Teachers: New directions for schooling? Milton Keynes: Open University Press, 138-50.

Ozga, J. (2005) 'Travelling and embedded policy: The case of post-devolution Scotland within the UK'. In Coulby, D. and Zambeta, E. (eds) World Yearbook of Education 2005: Globalization and nationalism in education. London: RoutledgeFalmer, 96-105.

Ozga, J. and Jones, R. (2006) 'Travelling and embedded policy: The case of knowledge transfer'. Journal of Education Policy, 21 (1), 1-17.

Papanastasiou, N. (2017) 'The practice of scalecraft: Scale, policy and the politics of the market in England's academy schools'. Environment and Planning A: Economy and Space, 49 (5), 1060-79.

Parisi, L. (2012) 'Digital design and topological control'. Theory, Culture and Society, 29 (4-5), 165-92.

Parker, R. (2007) 'Networked governance or just networks? Local governance of the knowledge economy in Limerick (Ireland) and Karlskrona (Sweden)'. Political Studies, 55 (1), 113-32.

Parreira do Amaral, M. (2019) 'Embedding education research in the European economic imaginary?'. In Parreira do Amaral, M., Steiner-Khamsi, G. and Thompson, C. (eds) Researching the Global Education Industry: Commodification, the market and business involvement. Cham: Palgrave Macmillan, 115-33.

Parreira do Amaral, M., Steiner-Khamsi, G. and Thompson, C. (eds) (2019) Researching the Global Education Industry: Commodification, the market and business involvement. Cham: Palgrave Macmillan.

Peck, J. and Theodore, N. (2015) Fast Policy: Experimental statecraft at the thresholds of neoliberalism. Minneapolis: University of Minnesota Press.

Rhodes, R.A.W. (1996) 'The new governance: Governing without government'. Political Studies, $44(4), 652-67$.

Rhodes, R.A.W. (1997) Understanding Governance: Policy networks, governance, reflexivity and accountability. Buckingham: Open University Press.

Rhodes, R.A.W. (2009) 'Policy network analysis'. In Goodin, R.E., Moran, M. and Rein, M. (eds) The Oxford Handbook of Public Policy. Online. https://tinyurl.com/y5k7udxe (accessed 11 August 2019).

Rhodes, R.A.W. (2012) 'Waves of governance'. In Levi-Faur, D. (ed.) The Oxford Handbook of Governance. Online. https://tinyurl.com/y4uxjj5c (accessed 11 August 2019).

Rizvi, F. and Lingard, B. (2010) Globalizing Education Policy. London: Routledge.

Robertson, R. (1994) 'Globalisation or glocalisation?' Journal of International Communication, 1 (1), 33-52.

Robertson, S.L. and Dale, R. (2008) '"Making Europe": State, space, strategy and subjectivities'. Globalisation, Societies and Education, 6 (3), 203-6.

Rosenau, J.N. (1997) Along the Domestic-Foreign Frontier: Exploring governance in a turbulent world. Cambridge: Cambridge University Press.

Sassen, S. (2007) A Sociology of Globalization. New York: W.W. Norton.

Sassen, S. (2013) 'When the global arises inside the national'. In Seddon, T. and Levin, J.S. (eds) World Yearbook of Education 2013: Educators, professionalism and politics: Global transitions, national spaces and professional projects. London: Routledge, 27-41.

Savage, G.C. (2018) 'Policy assemblages and human devices: A reflection on "Assembling Policy"'. Discourse: Studies in the cultural politics of education, 39 (2), 309-21. 
Shore, C. and Wright, S. (2011) 'Conceptualising policy: Technologies of governance and the politics of visibility'. In Shore, C., Wright, S. and Però, D. (eds) Policy Worlds: Anthropology and the analysis of contemporary power. New York: Berghahn Books, 1-25.

Smart, S., Hutchings, M., Maylor, U., Mendick, H. and Menter, I. (2009) 'Processes of middle-class reproduction in a graduate employment scheme'. Journal of Education and Work, 22 (1), 35-53.

Straubhaar, R. and Friedrich, D. (2015) 'Theorizing and documenting the spread of Teach for All and its impact on global education reform'. Education Policy Analysis Archives, 23 (44), 1-8. Online. https://doi.org/10.14507/epaa.v23.2055 (accessed 11 August 2019).

Suter, W.N. (2012) Introduction to Educational Research: A critical thinking approach. 2nd ed. Thousand Oaks, CA: SAGE Publications.

Takayama, K., Lewis, S., Gulson, K. and Hursh, D. (2017) 'Review - Fast Policy: Experimental statecraft at the thresholds of neoliberalism, by J. Peck and N. Theodore'. Discourse: Studies in the cultural politics of education, 38 (2), 292-316.

Thomas, M.A.M. (2018a) " Good intentions can only get you so far": Critical reflections from Teach for America corps members placed in special education'. Education and Urban Society, 50 (5), 435-60.

Thomas, M.A.M. (2018b) "“Policy embodiment": Alternative certification and Teach for America teachers in traditional public schools'. Teaching and Teacher Education, 70, 186-95.

Thrift, N. (1999) 'Steps to an ecology of place'. In Massey, D., Allen, J. and Sarre, P. (eds) Human Geography Today. Cambridge: Polity Press, 295-322.

Tompkins-Stange, M.E. (2016) Policy Patrons: Philanthropy, education reform, and the politics of influence. Cambridge, MA: Harvard Education Press.

Wennström, J. (2016) 'A left/right convergence on the new public management? The unintended power of diverse ideas'. Critical Review, 28 (3-4), 380-403.

Williams, R. (2005) Culture and Materialism: Selected essays. London: Verso.

Wright, S. (2011) 'Studying policy: Methods, paradigms, perspectives: Introduction'. In Shore, C., Wright, S. and Però, D. (eds) Policy Worlds: Anthropology and the analysis of contemporary power. New York: Berghahn Books, 27-31.

Yin, Y.M., Dooley, K. and Mu, G.M. (2019) 'Why do graduates from prestigious universities choose to teach in disadvantaged schools? Lessons from an alternative teacher preparation program in China'. Teaching and Teacher Education, 77, 378-87. 